УДК 007.51

Р. І. Дзінько, О. І. Лісовиченко

\title{
ПРИХОВАНА МАРКІВСЬКА МОДЕЛЬ НАДІЙНОСТІ ВИРОБНИЧОЇ СИСТЕМИ
}

Анотація: запропонована модель надійності гнучкої виробничої системи на базі математичного апарату прихованих марківських моделей.

Ключові слова: система оперативного управління, гнучка виробнича система, прихована марківська модель, надійність, управління.

\section{Ветуп}

В роботі гнучких виробничих систем (ГВС) неминуче виникають нештатні ситуації. У випадку реалізації системи оперативного управління (СОУ) ГВС з застосуванням синхронної імітаційної моделі, оперативне управління грунтується на використанні деякій математичній моделі ГВС, що імітує роботу ГВС паралельно з реальною системою, та в реальному часі відображає стан цієї системи. Працездатність такої моделі повністю залежить від інформації, що надходить від інформаційної підсистеми (IП) ГВС, компонентами якої є система датчиків та засобів передачі даних, що передають інформацію, на базі якої формується імітаційна модель [1].

В даній роботі пропонується підхід до моделювання надійності роботи ГВС на базі апарату прихованих марківських моделей (ПММ), що не є класичним з точки зору теорії надійності технічних систем, де такі моделі, зазвичай, будуються на базі структурних та функціональних карт надійності.

Приховані марківські моделі успішно застосовуються в різних галузях науки i техніки, де $е$ потреба у відновленні зашумлених послідовностей даних. Поломки датчиків, а також засобів передачі даних ІП ГВС призводять до того, що імітаційна модель не може бути достовірною за відсутністю необхідної актуальної інформації про стан виробництва, окрім випадку, коли така модель уміє опрацьовувати нештатні ситуації описаного характеру [2].

Приховані марківські моделі успішно застосовуються в задачах розпізнавання голосу, при корекції сигналів в телекомунікаційних мережах тощо. Проте важливою відмінністю вказаних застосувань від

(C) Р. І. Дзінько, О. І. Лісовиченко 
поточної задачі моделювання виробництва є те, що в них послідовність подій $є$ марківською. При моделюванні ж виробництва ймовірність виникнення тієї чи іншої події (наприклад, поломки датчика) може формуватись під впливом цілого ряду факторів [5]. В даній статті розглядається саме такий випадок.

\section{Постановка задачі}

Розробити математичну модель виробництва для застосування в рамках СОУ ГВС з синхронною моделлю в якості імітаційної моделі [1].

Модель повинна бути стійкою до роботи в умовах невизначеностей, тобто враховувати втрати інформації з IП СОУ ГВС з можливістю їх відновлення хоча б за певний встановлений проміжок часу.

Кожна ГВС складається 3 компонентів, до яких відносять гнучкі виробничі модулі (оброблюючі ресурси), автоматизовані транспортні модулі, автоматизовані модулі контролю якості, автоматизовані склади, та ін. Для прикладу, на рис. 1 зображена гнучка автоматизована ділянка (ГАД) ГВС з двома ГВМ та конвеєром.

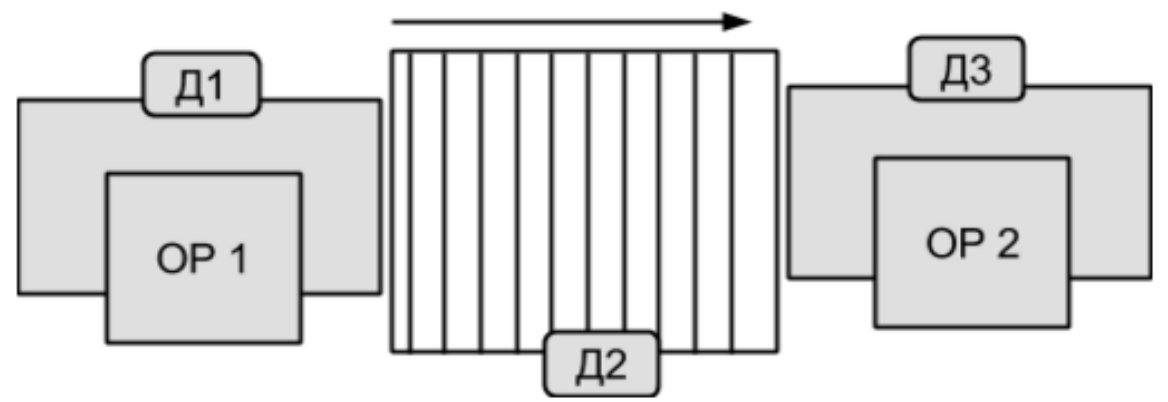

Рис. 1 Ділянка ГВС, що містить два оброблюючих ресурса (OP1, OP2) та конвеєр, оснащені датчиками (Д1, Д2, Д3)

Для повноцінної роботи СОУ ГВС з синхронною моделлю кожен 3 цих модулів оснащується датчиками (рис. 1), що сигналізують про їх перебування в певному стані, а деякі 3 них можуть мати також вбудовані датчики. Кожен з цих датчиків може виходити з ладу, що призведе до втрати даних і неможливості роботи імітаційної моделі СОУ ГВС, чим і зумовлені вищенаведені вимоги до математичної моделі.

\section{ПММ компонента виробничої систели}

Як вже було зазначено в попередніх роботах [2, 5], побудова ПММ в масштабах виробничої системи, чи навіть виробничої ділянки, є недоцільною, а активація моделі в СОУ відбуватиметься в момент, коли 
була виявлена нештатна ситуація (HC), а сама модель будуватиметься лише для компонента системи, в якому ця ситуація відбулась.

Таким чином, розглянемо подання компонента виробничої системи як прихованої марківської моделі у загальному вигляді [3]:

$$
\lambda=(S, \Omega, \pi, A, B) .
$$

Тут модель визначена на множині станів компонента виробничої системи $S$ та множині видимих подій $\Omega$. Початкові ймовірності знаходження компонента в певному стані задані вектором $\pi$. Останні два параметри моделі - матриця ймовірностей переходу компонента між станами внаслідок виникнення деякої події з послідовності подій $Q$ :

$$
A=\left[a_{i j}\right], a_{i j}=P\left(q_{t}=s_{j} \mid q_{t-1}=s_{i}\right),
$$

де $a_{i j}$ - ймовірність переходу компонента зі стану $s_{i}$ в стан $s_{j}, q_{t}$ - подія з послідовності подій $Q$; та матриця ймовірностей спостереження видимої події при знаходженні системи в певному стані:

$$
B=\left[b_{i}(k)\right], b_{i}(k)=P\left(x_{t}=v_{k} \mid q_{t}=s_{i}\right),
$$

де $v_{k}$ - ймовірність виникнення події при знаходженні системи в стані $s_{i}$. Важливим моментом $\mathrm{e}$ те, що ці ймовірності задаються як незалежні від часу для обох матриць $(2,3)$.

\section{Параметри ПММ для компонента виробничої системи}

Розглянемо зміст кожного з елментів ПММ, перейшовши, таким чином, від загального вигляду до конкретної моделі компонента ГВС:

- Набір станів $S$. Підбирається індивідуально в залежності від оснащеності відповідного компонента ГВС сенсорами, що дають можливість фіксувати ці стани [5]. До цього також варто додати ще один стан $s_{f}$ - стан нештатної ситуації, при якому обладнання нездатне виконувати свої функції в рамках технологічного процесу, тобто маємо множину з $N+1$ станів:

$$
s=\left\{s_{1}, \ldots, S_{n}, s_{f}\right\}, n=1 \ldots N
$$

- Початковий вектор $\pi$. Відповідає стану системи в момент початку моделювання, тобто містить розподіл ймовірностей перебування компонента системи в певному стані з урахуванням 
точно відомого останнього стану обладання, зафіксованого сенcopom:

$$
\pi=\left\{\pi_{1}, \ldots, \pi_{n}, \pi_{f}\right\}, \mathrm{n}=1 . . \mathrm{N},
$$

де $\pi_{i}$ - ймовірність перебування модельованого компонента в деякому стані $s_{t}$.

Очевидно, що даний вектор міститиме $N$ нульових елементів та один елемент зі значенням 1.

- Множина видимих подій $\Omega$. Формується за рахунок достовірних даних отриманих за допомогою сенсорів з обладнання, що приймає участь в виконанні наступної операції в технологічному ланцюжку операцій виробу (рис. 2).
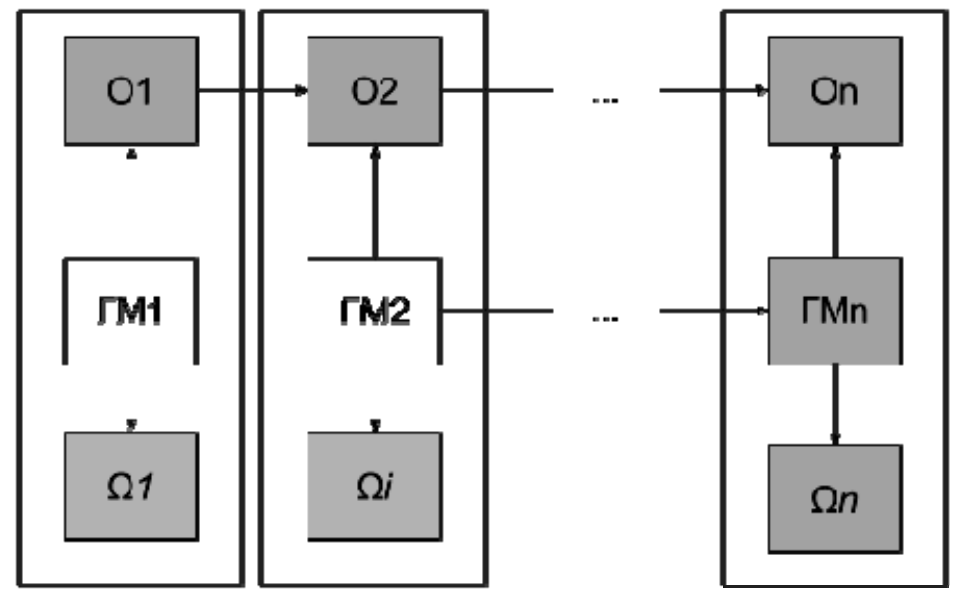

Моделюсться ланцюг технопогінних өперацій [Ö]. що әизналас стани $\mathrm{S}$

Датмикм компонентіз ГВС

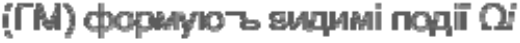

Рис. 2. Ланцюжок технологічних операцій та обладнання ГВС, що показує залежність видимих подій $\Omega_{i}$ від станів $S_{i}$

- Матриця $A$ ймовірностей переходів між станами (2). Формується на базі інформації про етапи виконання обладнанням технологічних операцій, що отримується з сенсорів [5].

Оскільки, ми маємо справу з параметрами надійності, на подані ймовірності впливатимуть параметри надійності компонентів ГВС: ймовірність $F(t)$ виходу з ладу компонента в певний момент часу

$$
F(t)=\left(\mathrm{t}-\mathrm{T}_{p}\right) / \mathrm{T}_{c p}
$$

де $T_{p}$ - час виникнення попередньої відмови, а $T_{\text {ср }}$ - середній час напрацювання на відмову, що залежить від закону розподілу інтенсивності відмов [2]. 
Як бачимо, характеристика надійності обладнання є величиною залежною від часу, а тому й комірки матриці міститимуть залежні від часу значення, що йде в розріз з класичною моделлю ПММ.

Для того, щоб нівелювати таку залежність, розділимо модель на $R$ етапів роботи, провівши квантування значень матриці в залежності від закону розподілу інтенсивності відмов, по часу, на весь період роботи обладнання від першого запуску до вилучення з виробництва. Таким чином, отримаємо значення для робочих станів:

$$
a_{i j}^{\tau}=a_{i j} \cdot \sum_{j=1 . . N} a_{i j}-F(t)=a_{i j} \cdot(1-F(t)),
$$

де $\tau=[1 . . R]$ - відповідний етап роботи модельованого обладнання в залежності від закону розподілу інтенсивності відмов, $a_{i j}$ - значення матриці ймовірності переходів обладнання між станами без урахування характеристик надійності обладнання, а $t$ - поточний час роботи обладнання з моменту початку експлуатації.

Фізичним змістом даної залежності є зростання ймовірності виникнення НС з часом роботи обладнання, що веде за собою зменшення ймовірностей переходів між працездатними станами.

Для прикладу, дану матрицю при лоделюванні надійності роботи фрезерного станка можна злінювати один раз на день, такил чинол враховуючи закон розподілу інтенсивності відлов.

В кінцевому варіанті в деякий дискретний період $\tau$, враховуючи також НС, матриця для всіх станів компонента ГВС виглядатиме як подано нижче (табл. 1).

Таблиия 1.

Матриця $A^{\tau}$ ймовірностей переходів компонента ГВС між станами

\begin{tabular}{|c|c|c|c|c|}
\hline$A^{\tau}$ & $a_{1}$ & $a_{2}$ & $\ldots$ & $a_{f}$ \\
\hline$a_{1}$ & $a_{11} \cdot(1-F(t))$ & $a_{12} \cdot(1-F(t))$ & $\ldots$ & $F(t)$ \\
\hline$a_{2}$ & $a_{21} \cdot(1-F(t))$ & $a_{22} \cdot(1-F(t))$ & $\ldots$ & $F(t)$ \\
\hline$\ldots$ & $\ldots$ & $\ldots$ & $\ldots$ & $F(t)$ \\
\hline$a_{f}$ & 0 & 0 & 0 & 1 \\
\hline
\end{tabular}


- Матриця $B$ ймовірностей виникнення видимих подій (3). Формується, як і вектор видимих подій $\Omega$, на базі інформації про ланцюжки технологічних операцій i обладнання, що їх виконує, окремо для кожного модельованого компонента ГВС. Особливістю даної матриці є те, що при відсутності НС, для кожного окремого технологічного ланцюжка операцій, ймовірності будуть приймати значення 0 чи 1, тобто залежності є повністю детермінованими.

Цей факт дає можливим приймати висновки про реальний стан, в якому знаходиться модельоване обладнання, навіть якщо з певних причин сенсори цього обладнання не надають такої інформації, а сама матриця матиме наступний вигляд (табл. 2).

Таблиця 2.

Матриця $B$ ймовірностей спостереження видимих подій

\begin{tabular}{|c|c|c|c|c|}
\hline$B$ & 1 & 2 & $\cdots$ & $k$ \\
\hline$s_{1}$ & $b_{1}(1)$ & $b_{1}(2)$ & $\cdots$ & $b_{1}(k)$ \\
\hline$s_{2}$ & $b_{2}(1)$ & $b_{2}(2)$ & $\cdots$ & $b_{2}(\mathrm{k})$ \\
\hline & $\ldots$ & $\cdots$ & $\cdots$ & $\cdots$ \\
\hline$s_{f}$ & 0 & 0 & 0 & 0 \\
\hline
\end{tabular}

Висновки

Побудована ПММ компонента ГВС є складовою комплексу заходів з підвищення надійності оперативного управління ГВС. Сама модель відображає послідовність подій (процес) роботи компонента, враховуючи ймовірність виникнення НС.

Характеристики апарату ПММ як такого дозволяють застосовувати алгоритми, здатні відновити найбільш ймовірну послідовність дій технологічного обладнання при втратах інформації з сенсорів IП СОУ ГВС.

В даній роботі розглядається модель в загальному вигляді, а також неявно розглянута ситуація, коли втрачається інформація лише з одного сенсора i, хоча, це покриває абсолютну більшість випадків, варто також в подальшому розглядати не лише сенсори зокрема, а й цілі гілки ІП СОУ ГВС, що і є завданням для подальших досліджень. 
Ще одним застереженням є те, що спосіб формування матриці $B$, описаний в даній роботі актуальний тільки для виробничих ліній без розгалуженої структури i, хоча, в мілкосерійному виробництві такі зустрічаються найчастіше, варто також розглянути i розгалужені структури технологічних ланцюжків.

\section{Список використаних джерел}

1. Система оперативного контролю виробництва з дублюючою синхронною моделлю / Дзінько Р. І., Лісовиченко О. І. // Міжвідомчий науково-технічний збірник «Адаптивні системи автоматичного управління». - 2013. - №1(22). - С. 10-16.

2. Підхід до вирішення задачі оперативного управління в гнучких виробничих системах в умовах невизначеностей / Дзінько Р. I., Лісовиченко О. I. // Міжвідомчий науково-технічний збірник «Адаптивні системи автоматичного управління». - 2015. - №2(27). - С. 51-55.

3. L. Rabiner. A tutorial on hidden markov models and selected applications in speech recognition. Proceedings of IEEE, 1989.

4. Суботін С. О. Подання й обробка знань у системах штучного інтелекту та підтримки прийняття рішень: Навчальний посібник. - Запоріжжя: ЗНТУ, 2008. - 341 с.

5. Підвищення відмовостійкості функціонування гнучких виробничих систем за допомогою прихованих марківських моделей / Дзінько Р. I., Лісовиченко О. I. // Міжвідомчий науковотехнічний збірник «Адаптивні системи автоматичного управління». - 2013. - №2(23). - С. 18-22. 